J. Perinat. Med. 7 (1979) 134
Behavioral states and state related heart rate and motor activity patterns in the newborn infant and the fetus ante partum

\section{A comparative study}

II. Computer analysis of state related heart rate baseline and macrofluctuation patterns

\section{H. D. Junge}

Department of Obstetrics and Gynecology, University of Würzburg, Germany
In part I of this publication [15] it has been demonstrated in detail that state related changes of heart rate pattern occur in the newborn infant and that visually identical heart rate patterns and their changes can be seen in the fetus too. On the basis of comparison and analogy it was assumed that in the fetus the regular change in the state of central nervous coordination and/or arousal as in the newborn - is the predominating factor governing ante partum FHR pattern and its variation in fetal wellbeing.

The striking similarity of heart rate patterns in the newborn and the fetus was demonstrated by a series of original and compressed strip chart records. This similarity is reflected in results of our computer analysis of heart rate baseline and macrofluctuation patterns and these results will be presented here.

\section{Material and Method}

General items of material and method have been described in part I of this paper.

Time coded analog recordings of heart rate from 18 fetuses and 16 newborn infants had been stored on tape. Duration of each recording was 8 hours continuously.

For off line computer analysis all recordings were digitized with $2 \mathrm{~Hz}$ sample rate and data of se- quential segments of 1 min duration (= 480 segments per recording) were analysed in respect to baseline level, amplitude as well as frequency of macrofluctuation and microfluctuation. This was done according to quantification methods developed by the author (see below). The computer program (hp BASIC) for automatic control of segment-by-segment play back from tape via SYSTRON-DonNer Model 8140 Tape Search Unit, digitizing (INTERTEChNiQue Model Physiocope) and analysing heart rate (HEwLETT-PACKARD Model 9830 A Minicomputer) had been written by the author. A block diagram of the equipment used in our laboratory is seen in Fig. 1.

During a preliminary subroutine heart rate samples that deviated more than $15 \mathrm{bpm}$ from the previous sample or from the baseline level of the previous 1-min-segment were taken as artefacts and eliminated in toto. Because of restriction in hard ware power this subroutine did not identify and eliminate samples from deviations, i.e. from accelerations and decelerations. Preliminary output was done in form of tables (HewLETT-PACKARD 9866 Printer) and sequential histogram plots (HEwLETTPACKARD 9862 Plotter). Output data were stored on tape cassette for further subroutines as well.

Further subroutines included elimination of heart rate deviation values (see below), rearrangement of data for plotting statistical histograms of baseline 


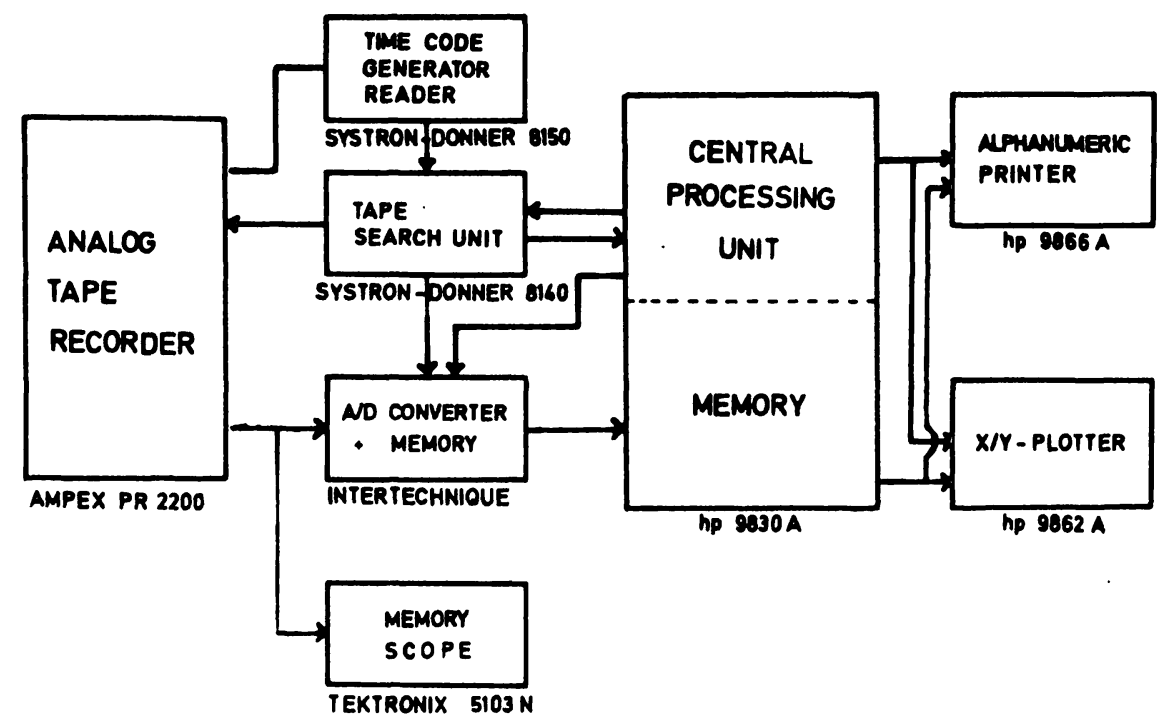

Fig. 1. Block diagram of electronic equipment for off line analysis of time coded signals used in our laboratory

and amplitude as well as frequency of macrofluctuation together with their order statistics and plotting scattergrams of amplitude versus frequency of macrofluctuation.

The author's concept of analysis closely follows the rules of visual FHR analysis [2,7-11, 17]).

The components of FHR pattern are defined as follows:

1. Baseline is defined as the statistical mean of heart rate when no deviations from baseline are present.

2. Deviations from baseline are accelerations and decelerations.

3. Macrofluctuation of baseline is the variation of heart rate around its statistical mean. It is the assumption made that macrofluctuation is composed of sine waves of various amplitudes and frequencies and as quantitative measures - as in visual analysis - the mean amplitude per min and the mean frequency per min are calculated in beat per minute (BPM) and cycles per minute (CPM).

4. Microfluctuation is defined as the high frequency component of sampled heart rate or beat-tobeat-irregularity, which is separated from macrofluctuation by a moving average window working like a filter. As a quantitative measure the mean absolute deviation of sampled heart rate from the slightly smoothed heart rate is calculated in BPM.

Off line analysis of sequential $1 \mathrm{~min}$ segments included the following computational steps:

$$
\text { ( } N=120 \text { at } 2 \mathrm{~Hz} \text { sample rate) }
$$

\section{Computation of baseline $\bar{B}$}

$\overline{\mathrm{B}}=\frac{1}{\mathrm{~N}} \cdot \sum_{\mathbf{i}=1}^{\mathrm{N}} \mathbf{x}_{\mathbf{i}}$

2. Next macrofluctuation and microfluctuation are separated by a moving average window of width W

$$
\begin{aligned}
\bar{X}_{i}=\frac{1}{W} \cdot \sum_{j=i-\left(\frac{W-1}{2}\right)}^{i+\left(\frac{W-1}{2}\right)} X_{j} \\
W=7 \text { was found to be appropriate }
\end{aligned}
$$

3. Computation of mean macrofluctuation amplitude

$$
\overline{\mathrm{A}}=\mathrm{K}_{1} \cdot \sum_{\mathrm{i}=1+\left(\frac{\mathrm{W}-1}{2}\right)}^{\mathrm{N}-\left(\frac{\mathrm{W}-1}{2}\right)}\left|\overline{\mathrm{B}}-\overline{\mathrm{X}}_{\mathrm{i}}\right|
$$

where $K_{1}$ is a function of $N$ 
4. Computation of mean macrofluctuation frequency is

$$
\overline{\mathrm{F}}=\mathrm{K}_{2} \cdot \sum_{\mathrm{i}=1+\left(\frac{\mathrm{W}-1}{2}\right)}^{\sum_{\mathrm{N}}-\left(\frac{\mathrm{W}-1}{2}\right)}\left|\overline{\mathrm{X}}_{\mathrm{i}}-\overline{\mathrm{X}}_{\mathrm{i}-1}\right|-\sum_{\mid \mathrm{i}=1+\left(\frac{\mathrm{W}-1}{2}\right)}^{N-\left(\frac{\mathrm{W}-1}{2}\right)}\left|\overline{\mathrm{B}}-\overline{\mathrm{X}}_{\mathrm{i}}\right|
$$

where $\mathrm{K}_{2}$ is a function of $\mathrm{N}$

5. Computation of mean microfluctuation

$$
\bar{M}=\frac{1}{N-(W-1)}: \sum_{i=1+\left(\frac{W-1}{2}\right)}^{N-\left(\frac{w-1}{2}\right)}\left|X_{i}-\bar{X}_{i}\right|(B P M)
$$

Advantages and limitations of this concept will be discussed later.

\section{Results}

\subsection{Baseline}

From visual analysis of compressed 8 hour heart rate recordings it was our impression that baseline tends to be lower during NREM-sleep compared to REM-sleep.

For computer analysis of state dependent baseline changes some precautions had to be taken.

Because accelerations per definitionem do not belong to baseline all values computed from 1-minsegments that coincided with accelerations or parts of accelerations had to be eliminated from the heart rate data files first. This was done by program subroutine after manual input of start times of all those 1-min-segments.

Next the influence from the nonstationarity of individual baseline in longlasting recordings as well as the influence from the interindividual dispersion of baseline levels had to be eliminated. In order to do so a series of sleep cycles of a NREM- and a REM-period were selected randomly. From these periods histograms of baseline values were computed for each of the two periods seperately in respect to absolute heart rate scale. Next these histograms were transponed to relative scales with the median of NREM-values as the zero class. This relative zero was $131 \pm 12 \mathrm{BPM}$ for the newborn and $133 \pm 8 \mathrm{BPM}$ for the fetus in absolute scale. At last all histograms.of NREM-values and all histograms of REM-valueswere added and plotted. Results revealed that our general impression from visual analysis was wrong.

\subsubsection{Newborn infant}

Histograms of relative baseline values for NREMsleep and REM-sleep are demonstrated in Fig. 2. During NREM-sleep the range of baseline values is small and during REM-sleep the range is increased more than 3 times. Because the histogram of NREMvalues is located within the range of REM-values no state dependent baseline shift can be verified.

For order statistics see Tab. I.

\subsubsection{Fetus}

Histograms of relative baseline values for assumed NREM-sleep and REM-sleep are demonstrated in Fig. 3. What has been found for the newborn infant heart rate can be found for the heart rate of the fetus too: No state related baseline shift occurs, but the range of baseline values is increased during REM-sleep compared to NREM-sleep.

For order statistics see Tab. I.

\subsection{Macrofluctuation pattern}

According to the principles of visual FHR analysis for statistical description of macrofluctuation again all acceleration values had to be eliminated from the heart rate data files. This had been done by a previous program subroutine (see above). Statistical histograms for amplitude and frequency of macrofluctuation as well as scattergrams of amplitude versus frequency were plotted. 


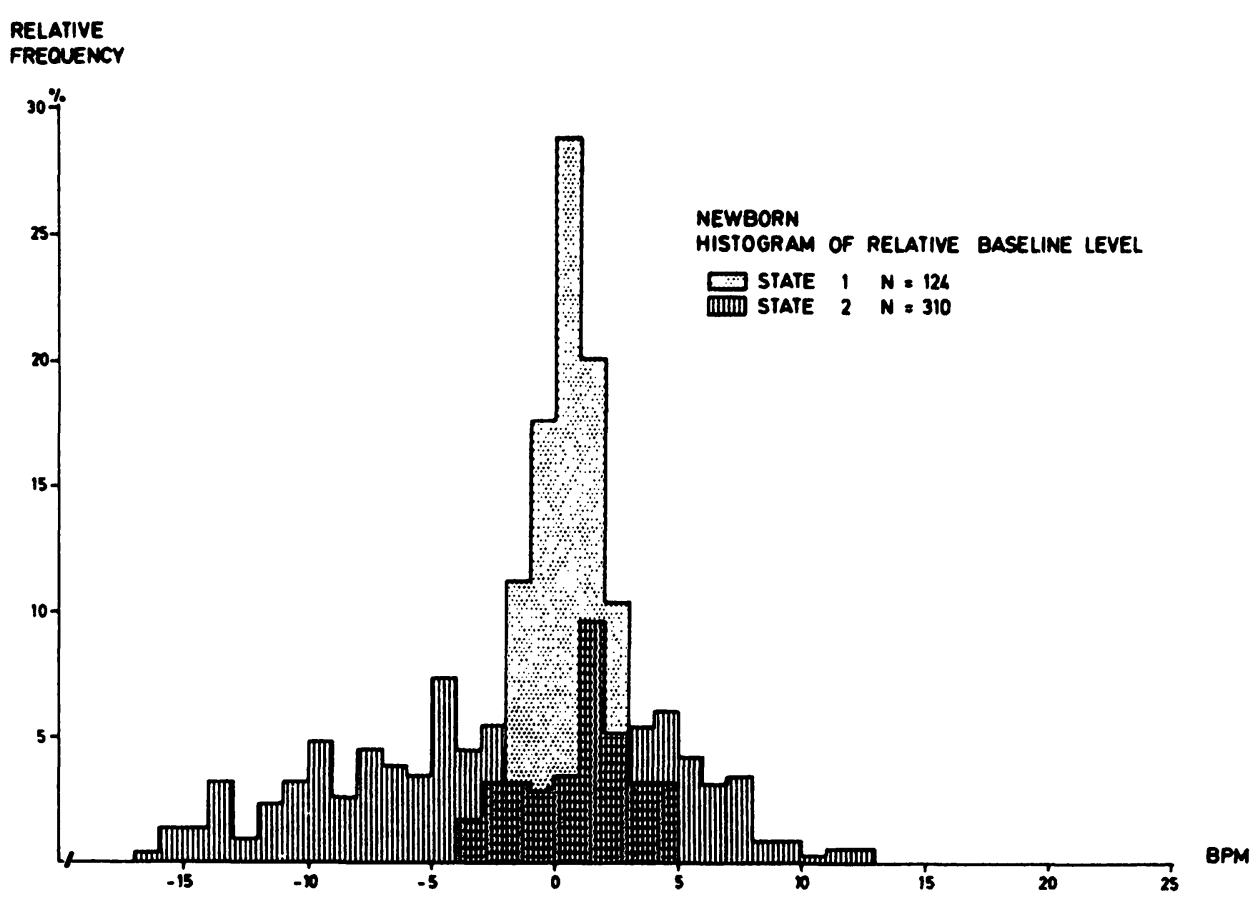

Fig. 2. Newborn

Histograms of relative baseline values for NREM- and REM-sleep. In order to eliminate the influence from the non stationarity of individual baseline in longlasting recordings as well as the influence from the interindividual dispersion of baseline levels all histograms of NREM- and REM-sleep values from randonly selected sleep cycles were transponed from the absolute to relative heart rate scales with the median classes of NREM-sleep being the zero class.

Tab. I. Order statistics of relative baseline distribution*

\begin{tabular}{lccccccccc} 
& $\mathrm{N}$ & $\mathrm{Min}$ & $\mathrm{Max}$ & Range & $\mathrm{D}_{1}$ & $\mathrm{Q}_{1}$ & Median & $\mathrm{Q}_{3}$ & $\mathrm{D}_{9}$ \\
\hline $\begin{array}{l}\text { NEWBORN } \\
\text { state 1 }\end{array}$ & 124 & -4 & 5 & 9 & -1.5 & -0.4 & 0 & 1.6 & 2.7 \\
state 2 & 310 & -17 & 13 & 30 & -10.5 & -6.9 & -1.5 & 3.2 & 6.1 \\
\hline $\begin{array}{l}\text { FETUS } \\
\quad \text { state 1 }\end{array}$ & 184 & -6 & 5 & 11 & -1.7 & -0.5 & 0 & 1.7 & 2.8 \\
$\quad$ state 2 & 431 & -14 & 23 & 37 & -3.8 & -0.7 & 3.7 & 8.8 & 14.4 \\
\hline
\end{tabular}

* In order to eliminate the influences from the dispersion of interindividual baseline levels and the influences from the nonstationarity of baseline in long lasting recordings the median class of each state 1 period histogram of selected sleep cycles was set to $\emptyset$. All baseline values of selected sleep cycles were rearranged according to this relative scale. All relative sleep cycle histograms were summed at last. $\left(D_{1}, D_{9}=\right.$ decile limits; $Q_{1}, Q_{3}=$ quartile limits)

\subsubsection{Newborn infant}

Fig. $4 \mathrm{a}$ presents histograms of macrofluctuation amplitude for NREM-sleep and REM-sleep. A highly significant difference in respect to location and dispersion can be seen: During NREM-sleep macrofluctuation amplitude ranges from 1 to $9 \mathrm{BPM}$ and during REM-sleep from 4 to $25 \mathrm{BPM}$. Skewness in both distributions is slightly positive. Fig. $4 \mathrm{~b}$ presents histograms of macrofluctuation frequency for NREM-sleep and REM-sleep. Frequency tends to be higher during NREM-sleep, although ranges are nearly identical (1.5 to 8.5 CPM for NREM-sleep and 1.5 to $7.5 \mathrm{CPM}$ for REM-sleep). From the scattergram of amplitude versus frequency (Fig. 4c) a negative correlation of values can be seen. This holds true for REMvalues separately as well but not for NREM-values.

For order statistics see Tab. II. 


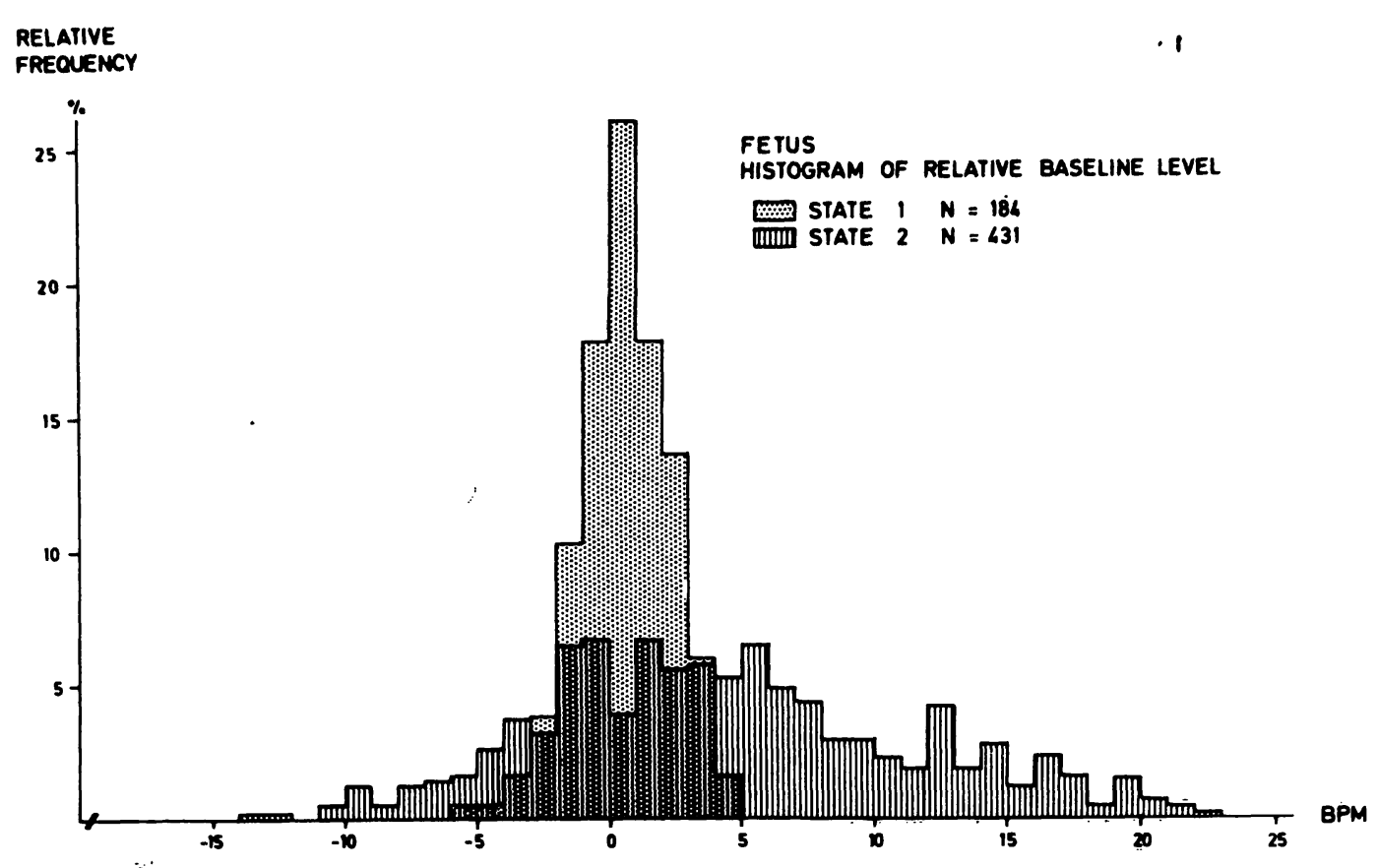

Fig. 3. Fetus

Histograms of relative baseline values for assumed NREM- and REM-sleep. (The same procedure of data handling as described in the legend of Fig. 2 was applied).

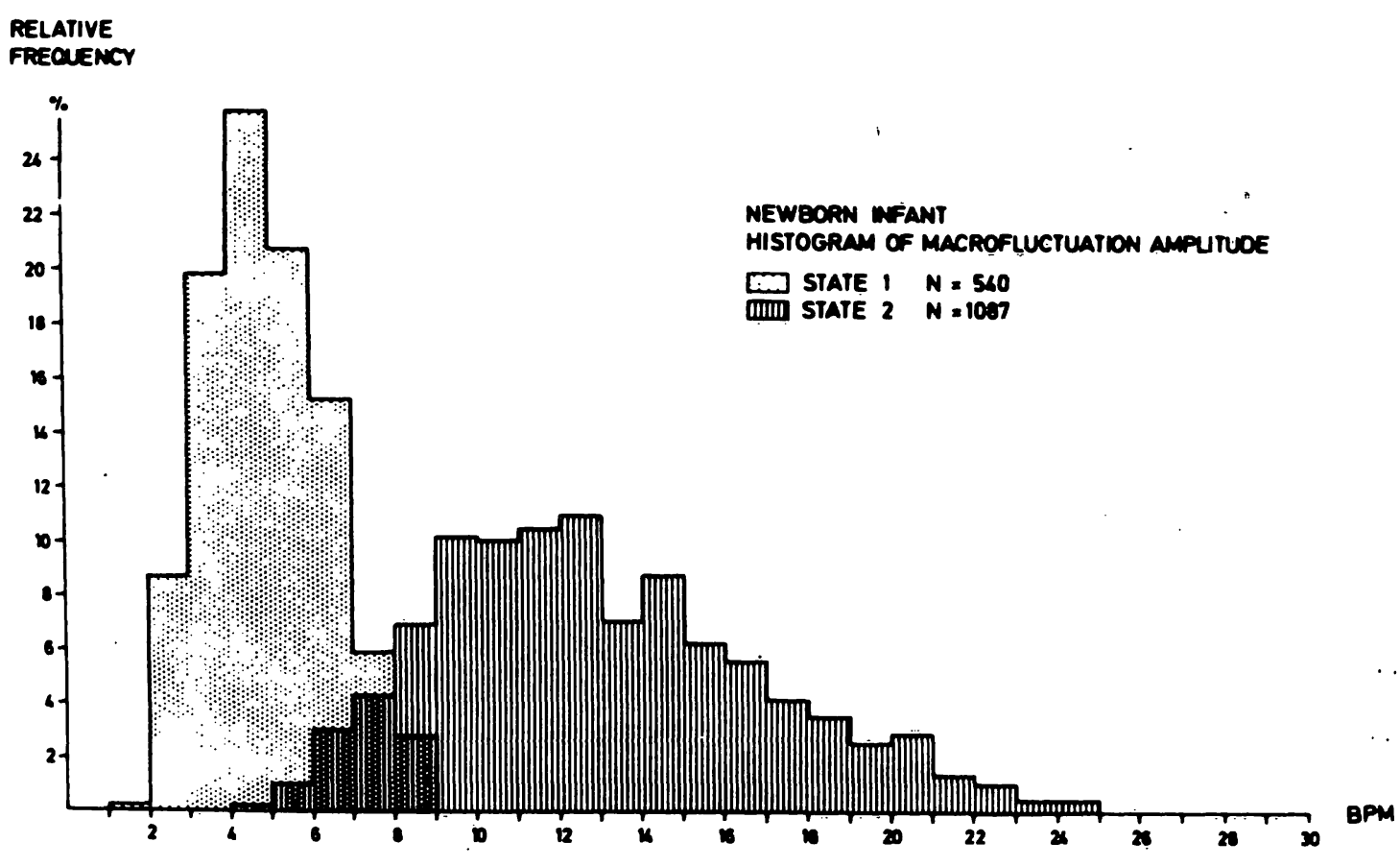

Fig. 4. Newborn

4a Histograms of macrofluctuation amplitude for NREM- and REM-sleep. 

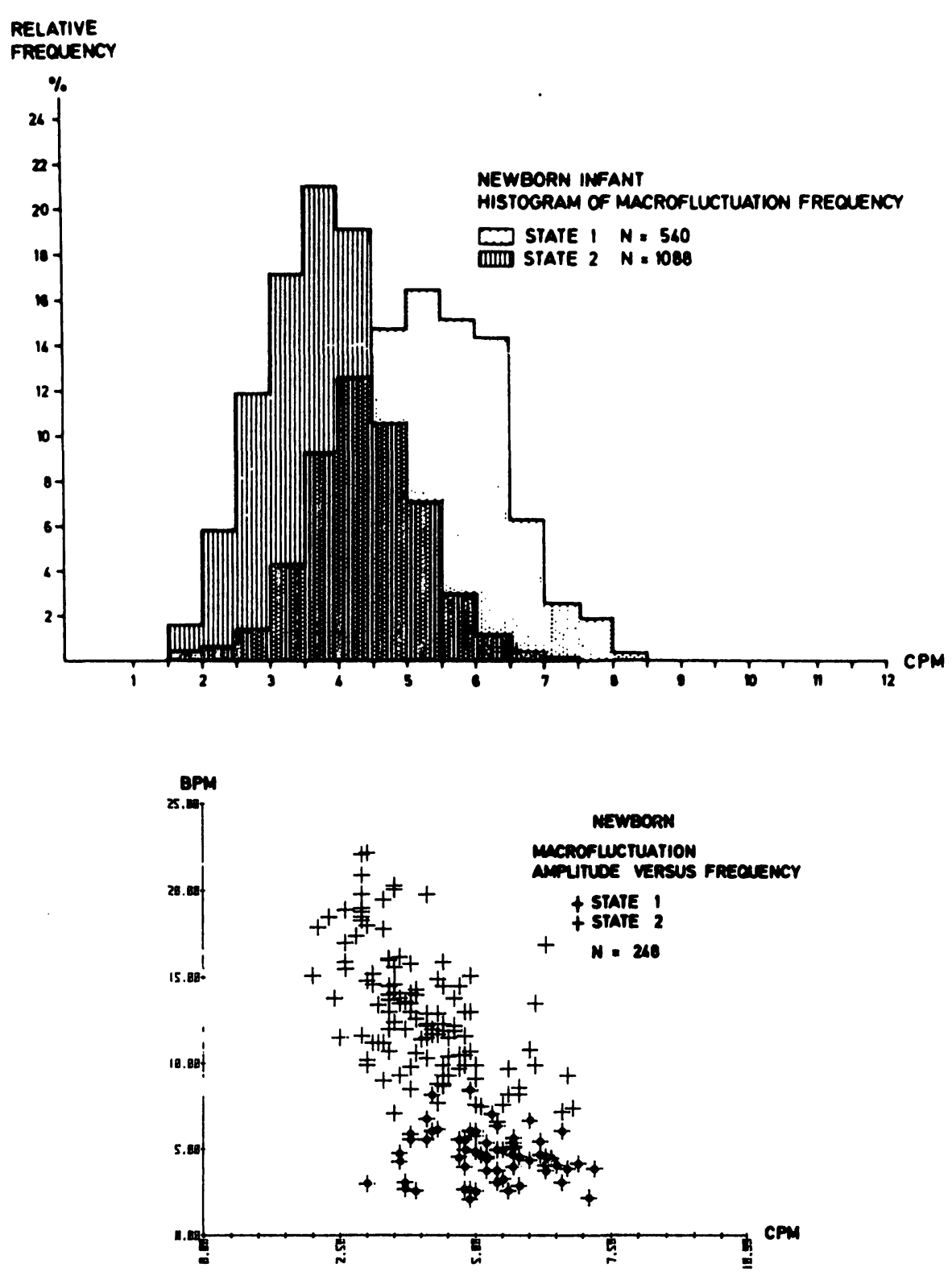

Fig. 4. Newborn

$4 \mathrm{~b}$ Histograms of macrofluctuation frequency for NREM- and REM-sleep.

4c Scattergram of macrofluctuation amplitude versus frequency for NREM- and REM-sleep. (For better demonstration in all scattergrams the number of values was reduced by random selection).

\subsubsection{Fetus}

Histograms of macrofluctuation amplitude and frequency for assumed NREM-sleep and REMsleep as well as the scattergram of amplitude versus frequency on the whole reflects the relations found for newborn infant macrofluctuation and differences are only gradual (Figs. $5 \mathrm{a}, \mathrm{b}$ and $\mathrm{c}$ ). For order statistics see Tab. II.
Results demonstrate the similarity of NREM- and REM-sleep macrofluctuation pattern s in the newborn infant and the fetus. This can be taken as a proof that identical heart rate patterns were identified visually in the heart rate tracings of the newborn infants and the fetuses and - with the assumption that heart rate patterns identical in the newborn and the fetus derive from identical states 
Tab. II. Order statistics of amplitude and frequency of macrofluctuation

.1

\begin{tabular}{|c|c|c|c|c|c|c|c|c|c|c|c|c|c|c|c|c|c|c|}
\hline & & & Amp & litude o & Mast & Nuct & vation & & & & & & quency & I Mac & ofluct & uation & & \\
\hline & $\mathbf{N}$ & Min. & Max. & Range & $D_{1}$ & $\theta_{1}$ & Median & $\theta_{3}$ & $D_{9}$ & $\mathbf{N}$ & Min. & Max & Range & $D_{1}$ & $Q_{1}$ & Median & $Q_{3}$ & $D_{g}$ \\
\hline $\begin{array}{r}\text { NEWBORN } \\
\text { state } 1 \\
\text { state } 2\end{array}$ & $\begin{array}{r}540 \\
1087\end{array}$ & $\begin{array}{l}1 \\
4\end{array}$ & $\begin{array}{r}9 \\
25\end{array}$ & $\begin{array}{r}8 \\
21\end{array}$ & $\begin{array}{l}2.0 \\
8.2\end{array}$ & $\begin{array}{l}3.8 \\
9.9\end{array}$ & $\begin{array}{r}4.8 \\
12.4\end{array}$ & $\begin{array}{r}5.9 \\
15.4\end{array}$ & $\begin{array}{r}6.9 \\
18.5\end{array}$ & $\begin{array}{r}540 \\
1088\end{array}$ & $\begin{array}{l}1.5 \\
1.5\end{array}$ & $\begin{array}{l}8.5 \\
7.5\end{array}$ & $\begin{array}{l}7 \\
6\end{array}$ & $\begin{array}{l}3.7 \\
2.6\end{array}$ & $\begin{array}{l}4.3 \\
3.0\end{array}$ & $\begin{array}{l}5.2 \\
3.8\end{array}$ & $\begin{array}{l}6.0 \\
4.4\end{array}$ & $\begin{array}{l}6.5 \\
5.1\end{array}$ \\
\hline $\begin{array}{l}\text { FETUS } \\
\qquad \begin{aligned} \text { state } 1 \\
\text { state } 2\end{aligned}\end{array}$ & $\begin{array}{r}924 \\
1559\end{array}$ & $\begin{array}{l}1 \\
2\end{array}$ & $\begin{array}{l}10 \\
25\end{array}$ & $\begin{array}{r}9 \\
23\end{array}$ & $\begin{array}{l}3.0 \\
6.5\end{array}$ & $\begin{array}{l}3.8 \\
8.7\end{array}$ & $\begin{array}{r}4.9 \\
11.8\end{array}$ & $\begin{array}{r}6.4 \\
17.2\end{array}$ & $\begin{array}{r}7.6 \\
21.8\end{array}$ & $\begin{array}{r}925 \\
1558\end{array}$ & $\begin{array}{c}1.5 \\
1\end{array}$ & $\begin{array}{l}9.5 \\
7.5\end{array}$ & $\begin{array}{c}8 \\
6.5\end{array}$ & $\begin{array}{l}3.1 \\
2.1\end{array}$ & $\begin{array}{l}3.9 \\
2.6\end{array}$ & $\begin{array}{l}4.7 \\
3.4\end{array}$ & $\begin{array}{l}5.5 \\
4.2\end{array}$ & $\begin{array}{l}6.3 \\
4.9\end{array}$ \\
\hline $\begin{array}{r}\text { FETus 09 } \\
\text { state } 1 \\
\text { state } 2\end{array}$ & 133 & 1 & 22 & 20 & $\begin{array}{l}2.5 \\
4.6\end{array}$ & $\begin{array}{l}2.4 \\
5.8\end{array}$ & 3.0 & $\begin{array}{r}4.0 \\
12.6\end{array}$ & $\begin{array}{r}5.7 \\
15.8\end{array}$ & $\begin{array}{r}88 \\
133\end{array}$ & 1 & 9 & 8 & $\begin{array}{l}3.2 \\
1.8\end{array}$ & $\begin{array}{l}4.0 \\
2.4\end{array}$ & $\begin{array}{l}4.8 \\
3.3\end{array}$ & $\begin{array}{l}5.9 \\
4.2\end{array}$ & \\
\hline
\end{tabular}

$\left(D_{1}, D_{9}=\right.$ decile limits; $Q_{1} / Q_{3}=$ quartile limits $)$

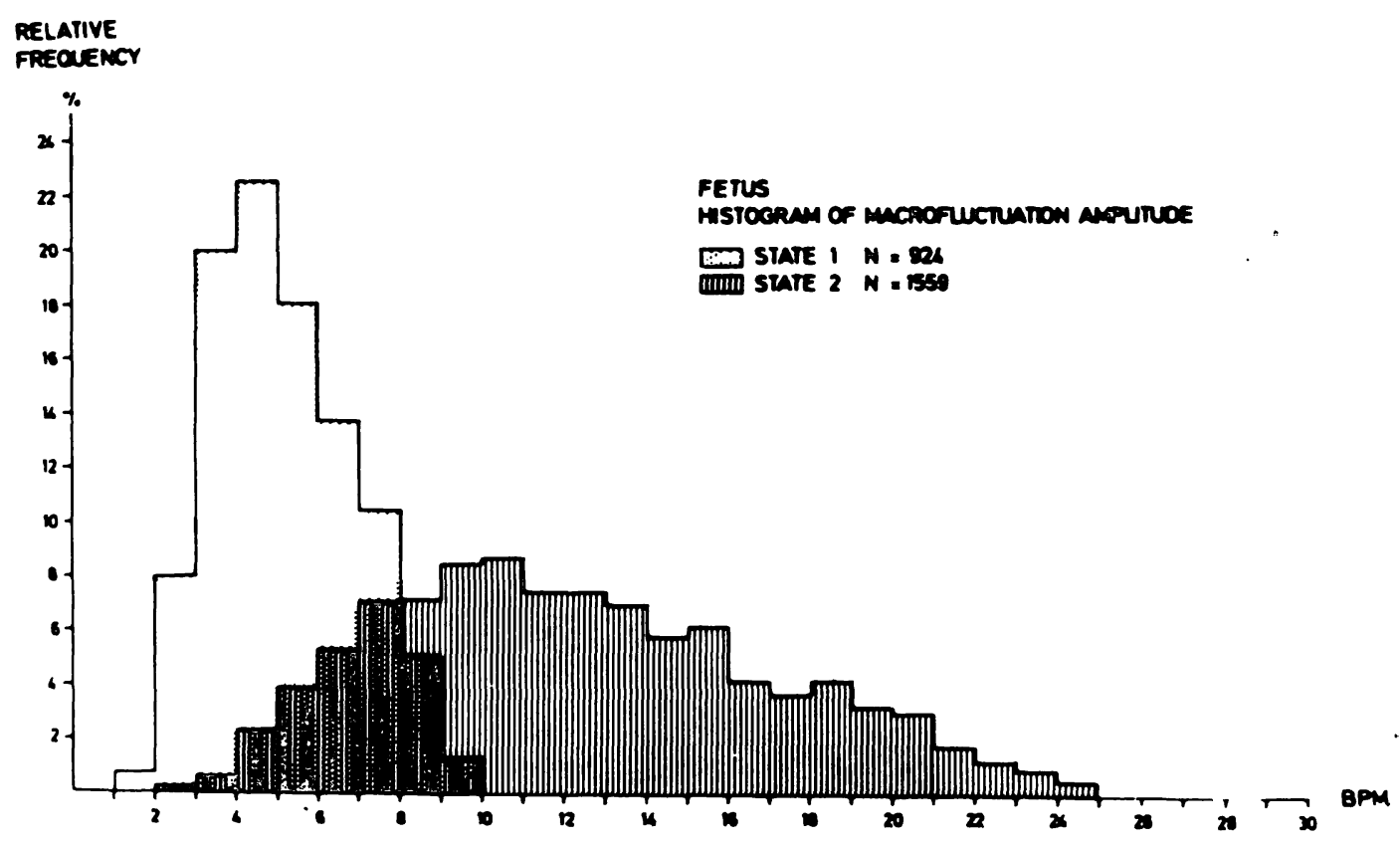

Fig. 5. Fetus

5 a Histograms of macrofluctuation amplitude for assumed NREM- and REM-sleep. 

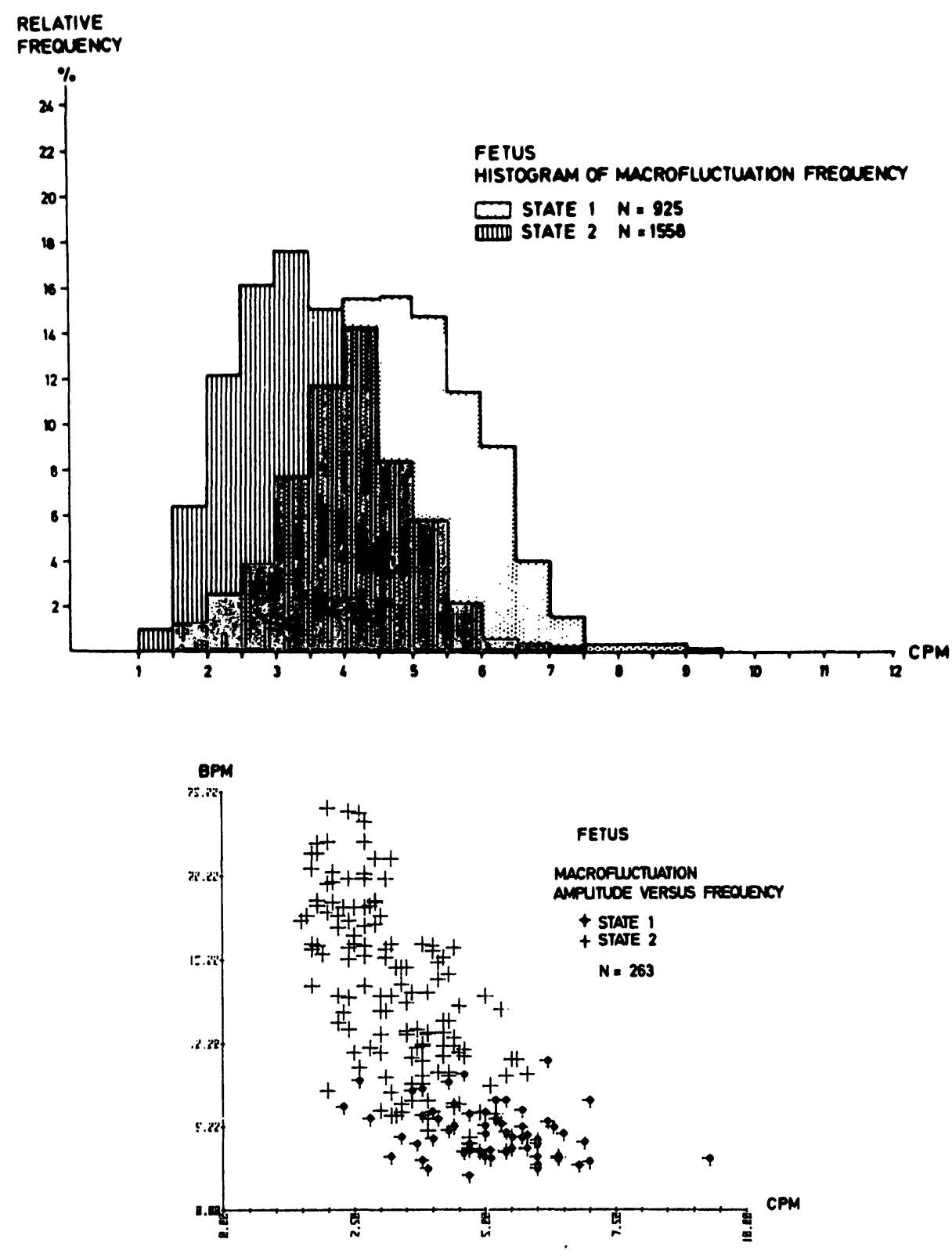

Fig. 5. Fetus

$5 \mathrm{~b}$ Histograms of macrofluctuation frequency for NREM- and REM-sleep.

$5 c$ Scattergram of macrofluctuation amplitude versus frequency for NREM- and REM-sleep.

of central nervous coordination - that our state scoring was correct.

\section{Effect of fetal distress on FHR macrofluctu- ation pattern}

In one fetus suspicion of fetal distress arose from antepartum monitoring prior to our recording and from the course of labor and delivery two days later. This suspicion was supported by FHR alterations seen in the 8 hour recording. During some of NREM-periods macrofluctuation was minimal and during REM-sleep macrofluctuation amplitude was diminished too. These alterations are reflected in the histograms of macrofluctuation amplitude and in the scattergram of amplitude versus frequency (Figs. $6 \mathrm{a}, \mathrm{b}$ and $\mathrm{c}$ ): in NREMsleep amplitude histogram shifts to the left and in 
REM-sleep amplitude histogram a peak appears at the lower edge. In the scattergram dots are arranged low down near the bottom.

For order statistics see Tab. II.

\section{Discussion}

\subsection{General considerations}

The action of the heart can be taken as an event process or a time series depending on which phenomenon is of interest: Heart action itself or the time intervals between heart actions.

Physiologists and information theorist in medical science are used to apply well established methods of time series analysis for evaluation and description of heart "rate" and for computer processing in this field the adequate method of analog to digital conversion is digital sequential time interval measurement, a method without problems.

Contrary to that obstetricians from tradition count the number of fetal heart beats per minute and eversince FHR monitors are in clinical use, obstetricians are accustomed to "instantaneous" FHR scaled in BPM. Visual analysis of FHR tracings until now has led to the definition of typical components of FHR pattern: baseline, macrofluctuation of baseline, microfluctuation (beat-to-beat-irregularity) and deviations from baseline, i.e. accelerations and decelerations. Rules for visual quantitation of these components have been established except for microfluctuation, which cannot be quantitated visually. Guidelines for ante partum and intrapartum intensive care presently are based on visual FHR analysis according to the above mentioned patterns and quantification rules.

Computer analysis of the instantaneous FHRsignal meets several problems. First of all from the general properties of this signal and from results of visual FHR analysis it is obvious that none of the methods of signal analysis established and applied in other fields can be applied for FHR analysis without severe restrictions. Therefore FHR analysis is open to new methodical approaches and developments. In doing so one has to have in mind, that all approaches have to be application

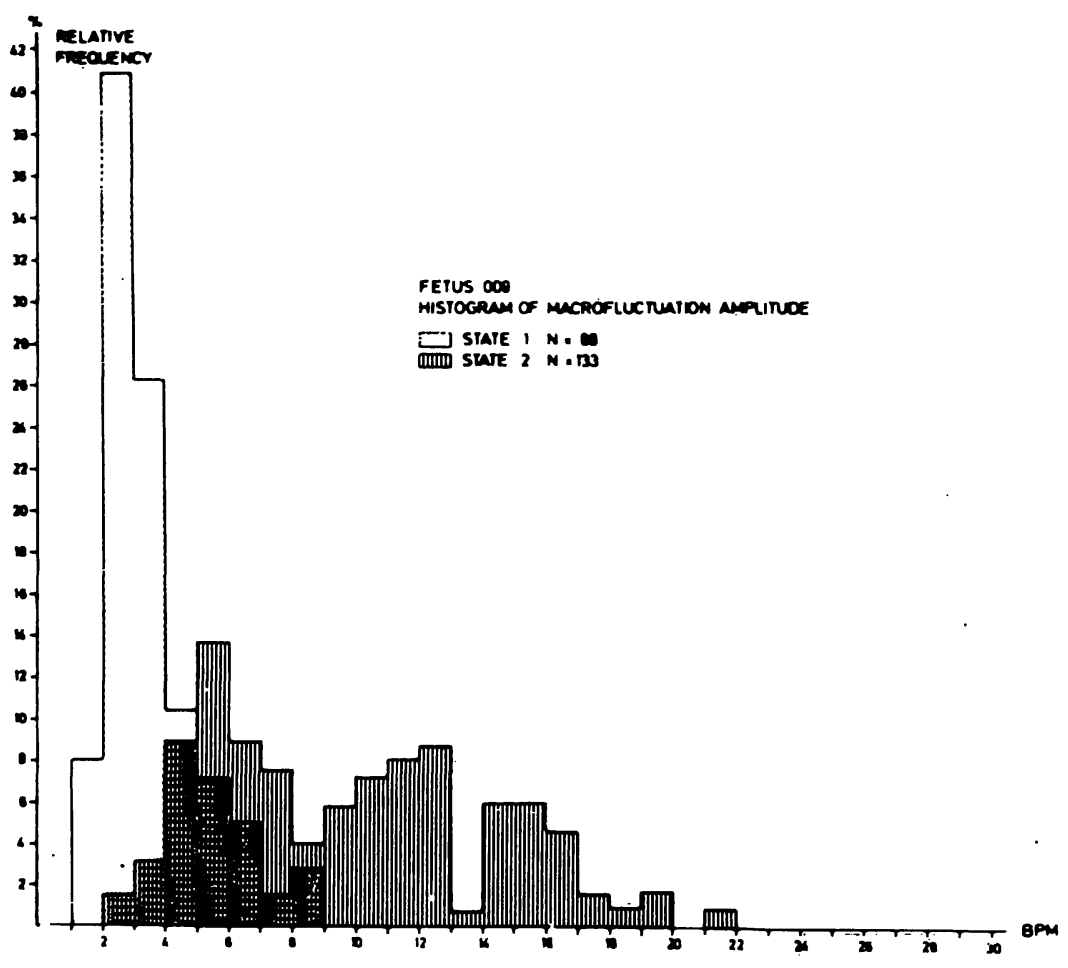

Fig. 6. Fetus

Macrofluctuation pattern of a fetus in beginning distress.

6a Histograms of macrofluctuation amplitude for assumed NREM- and REM-sleep. 

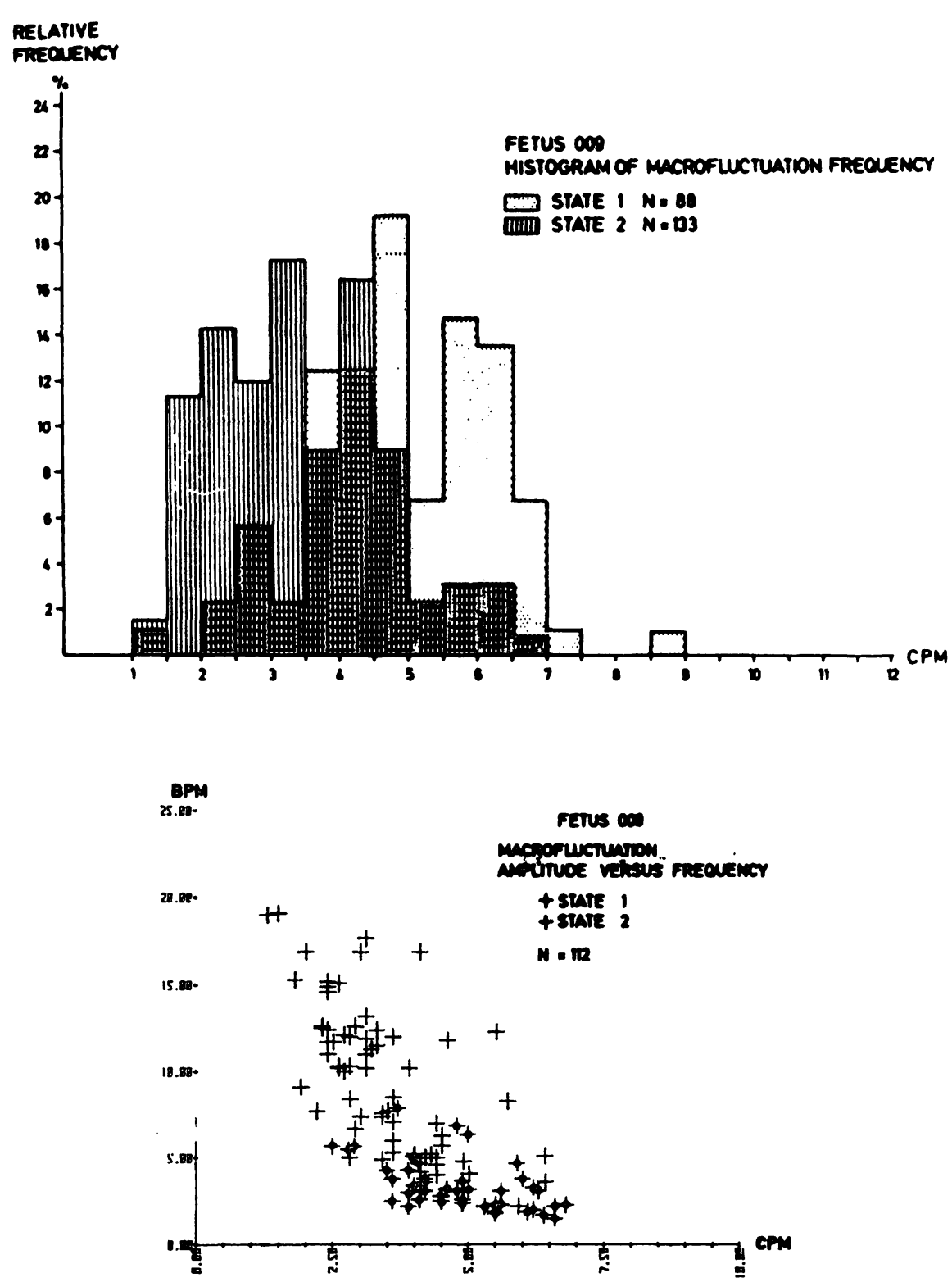

Fig. 6. Fetus

6b Histograms of macrofluctuation frequency for NREM- and REM-sleep.

6c Scattergram of macrofluctuation amplitude versus frequency for NREM- and REM-sleep.

orientated, which means analysis methods must be compatible with on line monitoring of the CTG using a CTG-Monitor System (CMS) (14) and analysis output must be clinically relevant, valid and acceptable for the obstetrician.

The latter would be met best by an FHR analysis method that directly imitates visual analysis, i.e. that defines and quantitates those FHR pattern components described above in measures the obstetrician is used to. It should be linked with an appropriate tocogram analysis method too.
These aims are difficult to accomplish because of problems from analog to digital conversion of instantaneous FHR and because of problems from adequate data processing algorhythms, especially in respect to macrofluctuation and microfluctuation. Therefore only a few proposals for computer analysis of macrofluctuation amplitude and frequency have been published $[3,6,12,13]$ and representative descriptive data for macrofluctuation based on large scale computer analysis have been missing. 
Contrary to that there are more and more proposals for quantitation of fetal (and neonatal) heart rate variability based on time interval measurement and simple to sophisticated methods of time series analysis $[1,4,5,16,18-26]$. Limitations of these approaches derive from the fact that measures for long term- and short term-variability are always sensitive to changes in baseline as well as their mutual influences and that measures are not conform with those all obstetricians are accustomed to from visual FHR analysis.

\subsection{The author's method of FHR computer analysis}

Methods for off line computer analysis presented here have been influenced to a large extent by studies on on line CTG analysis with a CTGMonitor-System (CMS) for clinical routine application [13, 14]. During these studies it turned out that the computational algorhythms given above on one hand are based on simple statistical processing methods, that are easily understood by clinicians and on the other hand these algorhythms in method and measures directly imitate the process of visual FHR analysis the clinician is accustomed to in every day work. According to the above given algorhythms baseline $\bar{B}$ is the statistical mean of heart rate per unit time. Computation of macrofluctuation amplitude A basically derives from computation of the mean absolute deviation of heart rate from its mean $\bar{B}$. Infact $\bar{A}$ represents twice the mean absolute peak deviation from baseline $\bar{B}$ per unit time. Macrofluctuation frequency $\overline{\mathrm{F}}$ represents the mean of the lower frequency spectrum contained in the heart rate per unit time. Because according to the rules of visualFHR analysis beat-to-beat irregularity, i.e. the high frequency component of heart rate is not included in evaluation of macrofluctuation, for computer analysis sampled heart rate is smoothed by a moving average algorhythm with a narrow window before computation of $\overline{\mathbf{A}}$ and $\bar{F}$. Microfluctuation $\bar{M}$ is the mean absolute deviation of sampled heart rate from the slightly smoothed heart rate per unit time. In that way the influence of baseline and the mutual influences of macrofluctuation and microfluctuation are decreased substantially.
To our opinion the method of FHR processing described here has the following advantages:

1. FHR processing is compatible with multiplex amplitude $\mathrm{A} / \mathrm{D}$-conversion of the FHR- and IUP-signals in CTG-Monitor-Systems.

2.FHR processing algorhythms are simple and easily understood. They can easily be modified for on line CTG monitoring. Therefore results of off line analysis are valid without restrictions for on line FHR monitoring done in the future.

3. Definition of measures $(\bar{B}, \bar{A}, \bar{F}, \bar{M})$ is identical with (or at least closely corresponds to) definitions of clinical routine visual FHR analysis. Clinical acceptance of a CMS working with these algorhythms and measures will be without problems in the future.

Intensive analysis of the method revealed that computation of $\bar{A}$ and/or $\bar{F}$ is slightly sensitive to their ratiós as well as to the phase shift between the fluctuating heart rate and sampling. These influences are minimized with higher sample rates and a $4 \mathrm{~Hz}$ sample rate was found to be optimal. (In order to reduce computation time in the off line program used at present sample rate was reduced to $2 \mathrm{~Hz}$, but analysis of an 8 hour FHR recording still lasted about 6 hours with our facilities).

As a consequence of the moving average smoothing of sampled heart rate, which works like a low pass filter, macrofluctuation amplitude is dampened in the higher macrofluctuation frequency range. But the $3 \mathrm{db}$ point for the window width used was found to be outside the range of normal macrofluctuation frequency.

Advantages and limitations of the author's concept of microfluctuation quantitation as well as results of microfluctuation quantitation of our heart rate recordings will be presented separately.

\section{Results}

Data for state related differences of heart rate patterns in the newborn infant have been published, but they cannot be compared directly with our results because, as has been mentioned, results of beat-to-beat time interval statistics are mutually influenced by baseline, macro-and microfluctuation . The same holds true for results of FHR analysis based on time interval statistics. 
The close similarity of data (see Tabs. and Figs.) for baseline and macrofluctuation amplitude as well as frequency in the newborn and the fetus on one hand is not surprising because a priori we were looking for visually identical heart rate patterns. Therefore the close similarity of results first of all can be taken as a proof that we indeed segmented and compared identical heart rate patterns in our recordings correctly. On the other hand results clearly demonstrate that identical patterns do exist.

Last not least our results strongly support our assumption that in the fetus as in the newborn a regular change of central nervous coordination does exist and the spontaneously changing central nervous coordination or arousal is the predominating factor governing antepartum FHR pattern and its variation in fetal wellbeing.

\section{Summary}

In part I of this publication it has been demonstrated that state related changes of heart rate pattern occur in the newborn infant and that visually identical heart rate pattern and their changes can be seen in the fetus too. On the basis of comparison and analogy it was assumed that in the fetus the regular change in the state of the central nervous coordination and/or arousal - as in the newborn - is the predominating factor governing antepartum FHR pattern and its variation in fetal wellbeing.

For off line computer analysis of visually identical neonatal and fetal heart rate patterns 8 hour heart rate recordings were digitized and data of sequential segments of $1 \mathrm{~min}$ duration were analysed in respect to baseline level, amplitude as well as frequency of macrofluctuation and microfluctuation. This was done according to quantification methods developed by the author.

The author's concept of analy sis closely follows the rules of visual FHR analysis. The components of FHR pattern are defined and quantitated as follows

1. Baseline is defined as the statistical mean of heart rate per unit time when no deviations from baseline are present. It is quantitated in beats per minute (BPM).

2. Deviations from baseline are accelerations and decelerations.

3. Macrofluctuation of baseline is the variation of heart rate around its statistical mean when no deviations are present. Macrofluctuation amplitude is defined as twice the mean absolute peak deviation from baseline per unit time. It is quantitated in BPM. Macrofluctuation frequency is the mean of the lower frequency spectrum contained in the heart rate per unit time. It is quantitated in cycles per min (CPM).
4. Microfluctuation is the high frequency component of heart rate. It is quantitated as the mean absolute deviation of sampled heart rate from the slightly smoothed heart rate per unit time in BPM.

\section{Results}

1 Baseline: In order to compare baseline values from NREM-sleep and REM-sleep the influence of the nonstationarity of individual baseline in longlasting recordings as well as the influence from interindividual dispersion of baseline levels had to be eliminated. After doing so analysis revealed that no state dependent baseline shift occurs but the range of baseline values for REM-sleep was increased more than 3 times in the newborn and the fetus compared to the range of baseline values for NREM-sleep.

2 Macrofluctuation pattern: For comparison of macrofluctuation patterns during NREM-sleep and REM-sleep in the newborn and the fetus histograms of macrofluctuation amplitude and macrofluctuation frequency as well as scattergrams of amplitude versus frequency were plotted. These demonstrate the similarity of NREM-sleep macrofluctuation patterns and the similarity of REMsleep macrofluctuation patterns in the newborn infant and the fetus.

3 Effect of fetal distress on FHR macrofluctuation pattern: In one fetus with suspicion of fetal distress during some of NREM-periods macrofluctuation was minimal and during REM-periods macrofluctuation amplitude was diminished too. These alterations are reflected in the histograms of macrofluctuation and in the scattergram of amplitude versus frequency: in NREM-sleep amplitude histogram shifts to the left and in REM-sleep amplitude histogram a peak appears at the lower edge. The scattergram is altered in parallel.

The close similarity of data for baseline as well as macrofluctuation amplitude and frequency in the normal newborn and in the fetus on one hand is not surprising because a priori we were looking for visually identical heart rate patterns. Therefore the close similarity of results first of all can be taken as a proof that we indeed segmented and compared identical heart rate patterns correctly. On the other hand the results clearly demonstrate that identical patterns do exist. Last not least our results strongly support our assumption that in the fetus as in the newborn a regular change of central nervous coordination does exist and that spontaneously changing central nervous coordination or arousal is the predominating factor governing antepartum FHR pattern and its variation in fetal wellbeing.

Keywords: Baseline, CNS activity, newborn, fetus, FHR monitoring, heart rate pattern, macrofluctuation, sleep cycle, state behavior. 


\section{Zusammenfassung}

Verhaltensweisen und verhaltensbedingte Herzfrequenz und motorische Aktivität des Neugeborenen und des Feten (2. Teil).

In Teil 1 dieser Publikation wurde demonstriert, daß beim Neugeborenen der Wechsel der Verhaltenszustände mit einem Wechsel verhaltenszustandstypischer Herzfrequenzmuster einhergeht. Es wurde ebenfalls demonstriert, daß visuell identische Herzfrequenzmuster im selben Wechsel auch beim Feten nachzuweisen sind. Aufgrund dieser Analogie ist anzunehmen, daß beim Feten wie beim Neugeborenen ein regelmäßiger Wechsel der zentralnervösen Koordination stattfindet und daß beim Feten wie beim Neugeborenen in gleicher Weise der spontane Wechsel der zentralnervösen Koordination der wesentliche Faktor (für die spontane Variation des Herzfrequenzmusters ist.

Zur Computeranalyse dieser visuell identischen neonatalen und fetalen Herzfrequenzmuster wurden die auf Analogband gespeicherten 8-Stunden-Registrierungen der Herzfrequenz digitisiert. Die Daten aller aufeinanderfolgenden 1-min-Segmente wurden dann nach einer vom Autor entwickelten Analysemethode in Bezug auf basales Frequenzniveau, Amplitude und Frequenz der Makrofluktuation und Mikrofluktuation quantifiziert.

Das Konzept der Analysemethode entspricht in Definition und Quantifizierung den Regeln der visuellen CTG-Quantifizierung.

\section{Ergebnisse}

Basales Frequenzniveau: Zum Vergleich der basalen Herzfrequenz in NREM- und REM-Schlaf bei Neugeborenen und Feten mußte der Einfluß der Nichtstationarität der individuellen Basalfrequenz in Langzeitregistrierungen und der Einfluß der interindividuellen Unterschiede der Basalfrequenz eliminiert werden. Zu diesem Zweck wurden alle Daten in relative Verteilungen überführt. Die Analyse dieser Verteilungen ergab keinen verhaltenszustandsbedingten Unterschied der Lageparameter, jedoch eine 3-fach größere Streuung der REM-Schlaf-Basalfrequenzwerte, verglichen mit den Werten im NREM-Schlaf. Dieses Ergebnis gilt für die Herzfrequenz des Neugeborenen und des Feten. $\cdot 1$

Makrofluktuation: Zum Vergleich des Makrofluktuationsmusters im NREM- und REM-Schlaf von Neugeborenen und Feten wurden Histogramme und Scattergramme von Makrofluktuationsamplitude und Makrofluktuationsfrequenz geplottet und Lage- und Streuungsparameter errechnet. Dabei zeigte sich einerseits die Übereinstimmung des NREM-Schlaf-Makrofluktuationsmusters und die Übereinstimmung des REM-Schlaf-Makrofluktuationsmusters von Neugeborenen und Feten. Andererseits wurde der visuell erkennbare Unterschied zwischen NREM-Schlaf- und REM-Schlaf-Makrofluktuationsmuster auch bei der Computeranalyse deutlich.

Effekt der fetalen Notsituation auf die Makrofluktuation der fetalen Herzfrequenž: Bei einem Feten mit Verdacht auf fetale Notsituation fand sich visuell in NREMPerioden eine minimale Makrofluktuationsamplitude. Die Amplitude war ebenfalls deutlich vermindert in den REM-Perioden. Die Computeranalyse ergab analoge $\mathrm{Be}-$ funde: Das Histogramm der Makrofluktuationsamplitudenwerte für den NREM-Schlaf war gegen Null verschoben. Im Histogramm der Makrofluktuationsamplitudenwerte für den REM-Schlaf zeigte sich ein zweiter Gipfel an der unteren Grenze der Verteilung.

Die Übereinstimmung der Ergebnisse unserer Computeranalyse verhaltenszustandstypischer Herzfrequenzmuster beim Neugeborenen und entsprechender Muster der fetalen Herzfrequenz ist einerseits nicht überraschend, denn es wurden a priori jeweils visuell identische Muster verglichen. Deșhalb ist diese Übereinstimmung zunächst nur ein Beweis dafür, daß tatsächlich identische Herzfrequenzmuster abgegrenzt und analysiert wurden. Andererseits beweist dièse Übereinstimmung jedoch klar, daß tatsächlich identische Herzfrequenzmuster beim Neugeborenen und Feten vorhanden sind. Damit wird letztlich die der gesamten Untersuchung zugrunde liegende Annahme gestützt, daß beim Feten wie beim Neugeborenen ein regelmäßiger Wech sel der zentralnervösen Koordination stattfindet und daß beim Feten ebenso wie beim Neugeborenen der zyklische Wechsel der zentralnervösen Koordination der wesentliche Faktor für die spontane Variation des Herzfrequenzmusters ist.

Schlüsselwörter:. Basalfrequenz, Fetus, FHF-Überwachung, Herzfrequenz-Muster, Makrofluktuation, Neugeborenes, Schlafverhalten, ZNS-Aktivität.

\section{Résumé}

Etats de comportement, état de rythme cardiaque relaté et échantillons d'activité motrice chéz le nouveau-né et le foetus ante partum

\section{Une étude comparative}

II. Analyse par ordinateur d'état de base du rythme cardiaque relaté et d'échantillons de macrofluctuation.

Dans la première partie de cette publication nous avons démontré que chez le nouveau-né l'alternation des états de comportement va de pair avec une alternation des échantillons de rythme cardiaque typiques pour l'état de comportement. Nous avons également démontré l'observation chez le foetus aussi d'échantillons de rythme cardiaque visuellement identiques dans la même alternation. En raison de cette analogie il est à supposer que chez le foetus comme chez le nouveau-né on assiste á une alternation rçguliére de la coordination nerveuse centrale et que cette alternation spontançe constitue pareillement chez l.un comme chez l.autre le facteur principal de la. variation spontançe de l.çchantillon du rythme cardiaque' 
Joachim Ufer

Joachim Ufer

H.-W. Boschann

\section{Hormontherapie in der Frauenheilkunde}

Grundlagen und Praxis

5. Auflage. $17,0 \mathrm{~cm} \times 24,0 \mathrm{~cm}$. XVIII, 285 Seiten. Mit zahlreichen Abbildungen und Tabellen. 1978. Gebunden DM 68,ISBN 3110066645

Die Vielzahl der neuen Befunde rechtfertigt die Herausgabe der 5. Auflage. Das Buch verfolgt in erster Linie das Ziel, Fachärzte, praktische Ärzte und Studenten über wichtige Fragen der gynäkologischen und der geburtshilflichen Endokrinologie zu informieren. Besondere Berücksichtigung fanden neue Erkenntnisse über die Releaser-Faktoren und über das Prolaktin. Diese Hormone haben in den letzten Jahren starke Beachtung gefunden. Ihre Bedeutung für Diagnostik und Therapie wurden umrissen. Eine beträchtliche Erweiterung erfuhr das Kapitel Hormonale Kontrazeptiva. Die Bestimmung der Hormone im Plasma wurde ebenfalls behandelt. Die Literatur wurde auf den neuesten Stand gebracht.

\section{The Principles and Practice of Hormone Therapy in Gynaecology and Obstetrics}

1969. $17,0 \mathrm{~cm} \times 24,0 \mathrm{~cm}$. VIII, 148 pages. 82 figures.

Paper DM 54,- ISBN 311006146

\section{Gynäkologische Zytodiagnostik für Klinik und Praxis}

2., völlig überarbeitete Auflage der „Praktischen Zytologie“ $15,5 \mathrm{~cm} \times 23,0 \mathrm{~cm}$. XVI, 179 Seiten. Mit 131 Abbildungen und 12 Tafeln mit farbigen Bildern. 1973. Gebunden DM 54,- ISBN 3110039818

In einer Zeit, in der Krebsvorsorgeuntersuchungen von der Offentlichkeit und den Krankenkassen gefördert werden, will das Buch dem Leser die Grundkenntnisse zu fundierter Zytodiagnostik von der Abstrichentnahme bis zur Auswertung des Befundes vermitteln.

Es wendet sich als Leitfaden für die tägliche Praxis an den Arzt und die technische Assistentin und informiert über Materialentnahme, Fixierung, Versand, Laboreinrichtungen, Färbung, Krebs- und zytohormonale Diagnostik (einschl. Urinsediment, Aszitespunktat und Mammazytologie) sowie spezielle Methoden wie Phasenkontrast- und Fluoreszenzmikroskopie.

Das Buch will helfen, die typischen Fehler bei der praktischen Anwendung der Zytodiagnostik zu vermeiden, und damit beitragen, den bisher häufigsten Krebs der Frau, das Portikarzinom, durch Erkennung der Vor- und Frühstadien als Invaliditäts- und Todesursache auszuschalten. 


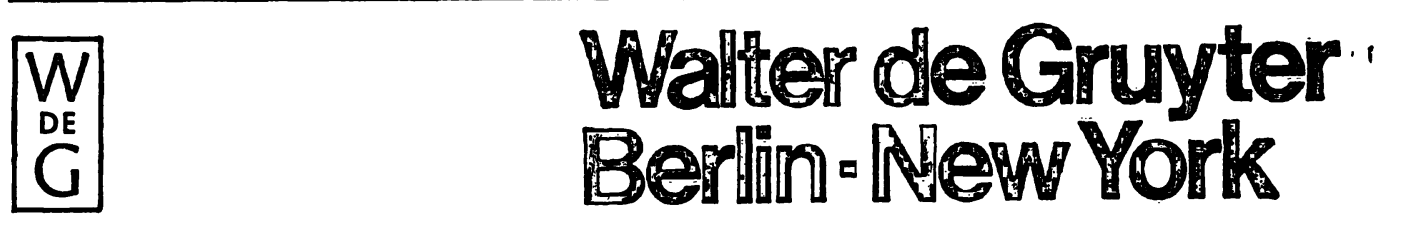

W. Pschyrembel

\section{Klinisches Wörterbuch}

mit klinischen Syndromen

und einem Anhang Nomina Anatomica

Gegründet von 0 . Dornblüth

253., um einen Anhang Nomina Anatomica erweiterte Auflage 1977.

$12,5 \mathrm{~cm} \times 20,5 \mathrm{~cm}$. XVI, 1389 Seiten. Mit 2293 Textabbildungen.

Gebunden DM 42,- ISBN 3110070189

Terminologie medizinischer Begriffe und Taschenenzyklopädie für die klinische Praxis.

Wichtige Krankheitszustände (Diagnostik, Differentialdiagnose, Prognose). Klinische Untersuchungs- und Arbeitsmethoden (neueste Entwicklung und Aussagewert)

Berücksichtigung der Fächer:

Pharmakologie, Mikrobiologie, Endokrinologie, Klinische Chemie, Humangenetik. Ein Tabellenanhang ergänzt die Artikel über Immunologie und Radiologie.

Diese Auflage wurde um einen Anhang Nomina Anatomica (Arteriae, Musculi, Nervi, Ossa, Venae) erweitert.

W. Pschyrembel

W. Pschyrembel

\section{Praktische Geburtshilfe}

und geburtshilfliche Operationen

14. Auflage, unter Mitarbeit von Jürg Bretscher und Dietrich Hofmann $14,0 \mathrm{~cm} \times 21,0 \mathrm{~cm}$. XXVIII, 899 Seiten. Mit 612 Abbildungen. 1973. Gebunden DM 74, - ISBN 3110016834

\section{Praktische Gynäkologie}

Für Studierende und Árzte

4., überarbeitete und erweiterte Auflage

$14,0 \mathrm{~cm} \times 21,0 \mathrm{~cm}$. XXIV, 642 Seiten. Mit 503, teils mehrfarbigen

Abbildungen. 1968. Gebunden DM 62,- ISBN 3110008068 

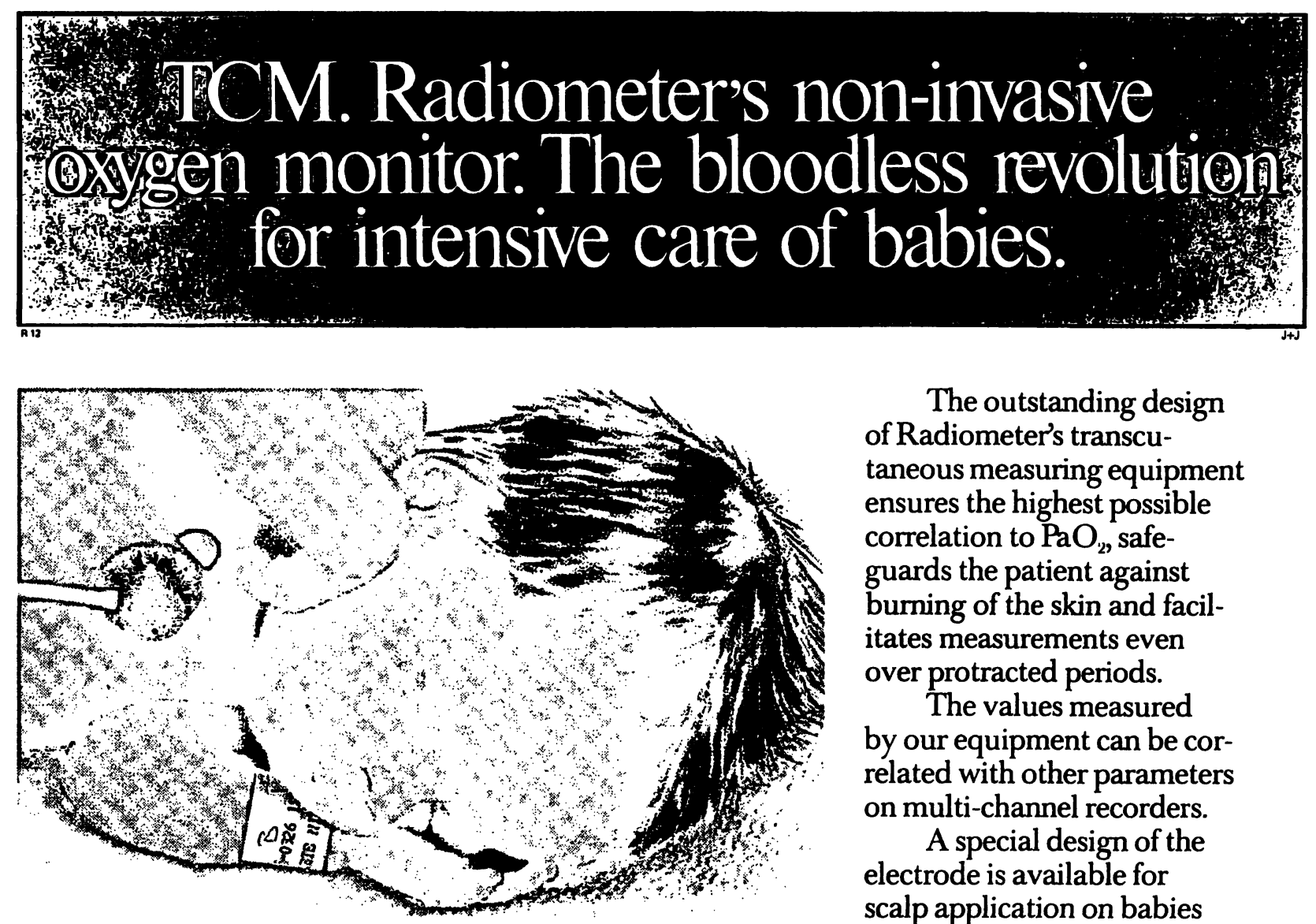

The outstanding design of Radiometer's transcutaneous measuring equipment ensures the highest possible correlation to $\mathrm{PaO}_{2}$, safeguards the patient against burning of the skin and facilitates measurements even over protracted periods.

The values measured by our equipment can be correlated with other parameters on multi-channel recorders.

A special design of the electrode is available for scalp application on babies during delivery.

Transcutaneous $\mathrm{Po}_{2}$

Monitoring of the oxygen status of patients in Neonatal Intensive Care has become practically possible by Radiometer's design of an innovative $\mathrm{Po}_{2}$ electrode measuring continuously and bloodlessly through the skin of the patient. The tc- $-\mathrm{Po}_{2}$ electrode transfers heat through the skin, hyperaemizing the dermal capillaries and making the skin permeable to oxygen. Variations in oxygen status are measured by the electrode placed on the skin - continuously and without discomforting the patient.

\section{Radiometer TCM features:}

Mono-micro cathode for low comsumption

Large electrode heat-transfer area

Separate fixation ring for safety

Sterile gel for rapid heat-transfer Audible/visual alarms for all parameters Recorder output for all parameters Operator-selectable temperatures, $35^{\circ}-45^{\circ} \mathrm{C}$ Calibration unit for high accuracy
The Radiometer TCM1 TC Oxygen Monitor is UL-approved and conforms to IEC regulations for patient safety.

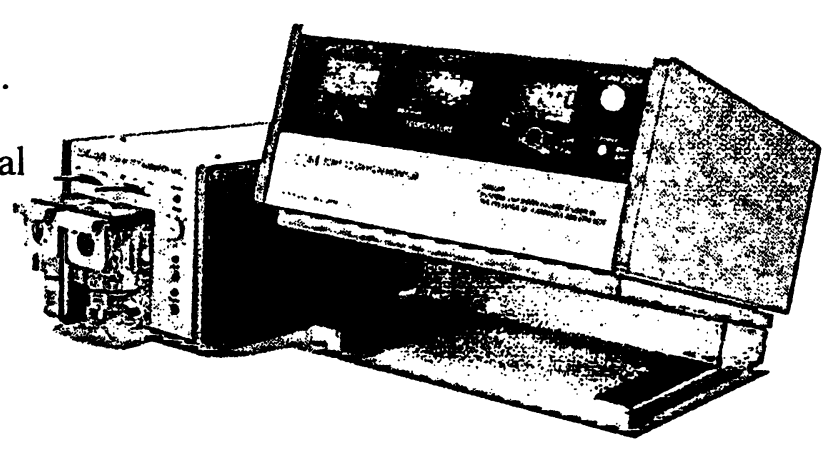




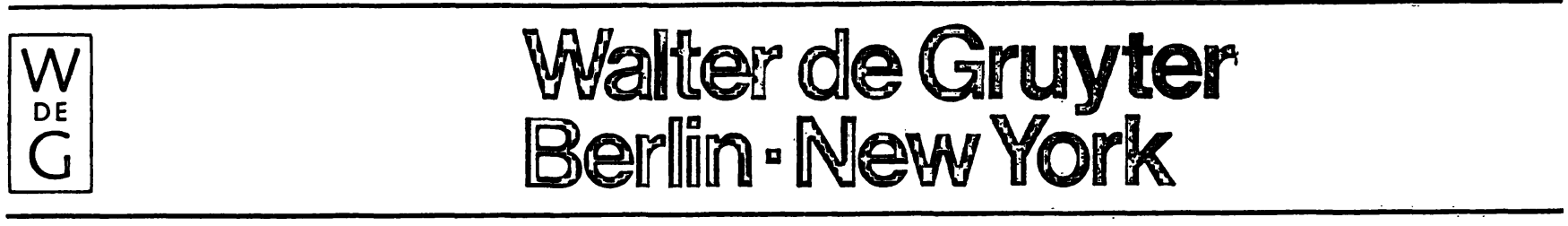

\section{Eduard Gitsch}

(Hrsg.)

\section{H. Götz}

E. S. Bücherl

(Editors)

\section{Radioisotope in Geburtshilfe und Gynäkologie}

Verfaßt von E. Gitsch, H. Janisch, S. Leodolter, W. H. F. Schnelder, J. Spona. Mit einem Geleitwort von Karl zum Winkel. Mit deutschen und englischen Zusammenfassungen. With summaries in German and English.

$17,0 \mathrm{~cm} \times 24,0 \mathrm{~cm}$. XX, 544 Seiten. Mit 139 Abbildungen. 1977. Gebunden DM 235,- ISBN $311004532 X$

Darstellung diagnostischer und therapeutischer nuklearmedizinischer Methoden, die für die moderne Geburtshilfe und Gynäkologie von Bedeutung sind.

Schwerpunkt: Die in der I. Universitäts-Frauenklinik Wien entwickelte Radioisotopen-Radikaloperation des Gebärmutterhalskrebses.

Aus dem Inhalt ferner: Grundlagen der Nuklearmedizin. Geburtshilflicher Teil (Nephrologie, Computer-Nephrographie; Venenthrombosen; Plazenta) Gynäkologischer Teil (Gynäkologische Lymphologie; Tumordiagnostik und Tumorimmunologie; die gynäko-urologische Radioisotopenoperation). Radioimmunologische Hormondiagnostik (der Radioimmunoassay; Pathologie des Zyklus; endokrin-bedingte pathologische Gravidität; endokrin-bedingte Sterilität; hormonale Kontrazeption; hormonbildende Tumore).

\section{Applied Tumor Immunology}

Methods of Recognizing Phenomena Specific to Tumors Proceedings of the First International Symposium Berlin, November 1972

1975. $17,0 \mathrm{~cm} \times 24,0 \mathrm{~cm}$. XII, 355 pages. Bound DM 125,-; $\$ 62.50$ ISBN 3110042428

Contents: Methods for detection of tumor-specific sensitized lymphocytes - Methods for detection of molecular antibodies against tumor proteins - Methods for detection of tumor cell surface antigens Methods for detection of non tumor antigens and fetal proteins Methods for detection of proteins excreted by tumor cells - Some clinical aspects. 
Pour l'analyse par ordinateur de ces échantillons de rythme cardiaque néonatal et foetal visuellement identiques, nous avons digitisé les enregistrements de huit heures consécutives stockés sur bande analogique. Les données de tous les segments successifs de $1 \mathrm{~min}$. Ont été quantifiées selon un procédé analy tique mis au point par l'auteur et basé sur le nivcau de fréquence basale, l'amplitude et la fréquence de macro et microfluctuation.

Le concept de cette méthode correspond dans sa définition et sa quantification aux règles de la quantification de CTG visuelle.

\section{Résultats}

Niveau de fréquence basale: Pour comparer le rythme cardiaque basal dans le sommeil NREM et REM chez le nouveau-né et le foetus, il a fallu éliminer l'influence de la non-stationarité de la fréquence basale individuelle dans les enrcgistrements de longue période et l'influence des différences inter-individuelles de la fréquence basale. Pour cela, nous avons converti toutes les données en répartitions relatives. L'analyse de ces répartitions n'a montré aucune différence conditionnéc par l'état de comportement dans les paramètres de position, mais indiqué une dispersion des valeurs de fréquence basale en sommeil REM trois fois plus grande que pour les valeurs enregistrées en sommeil NREM. Ce résultat vaut pour le rythme cardiaque aussi bien du nouveau-né que du foetus.

Macrofluctuation: Pour comparer l'échantillon de macrofluctuation dans le sommeil NREM et REM des nouveauxnés et des foetus, nous avons fait le graphique des histogrammes et scattergrammes de l'amplitude et de la fréquence de macrofluctuation et avons calculé les paramètres de position et de dispersion. Nous avons pu alors observer la concordance des échantillons de macrofluctuation en sommeil NREM et la conformité des échantillons de macrofluctuation en sommeil REM chez les nouveauxnés ct les foetus, mais nous avons relevé, par contre, une différence visuelle très nette- apparente aussi dans l'analyse par ordinateur - entre les échantillons de macrofluctuation pour les sommeils NREM et REM.

Effet de la situation d'urgence foetale sur la macrofluctuation du rythme cardiaque foetal: Chez un foetus avec soupcon de situation d'urgence foetale nous avons observé visuellement une amplitude minimale de macrofluctuation dans les périodes NREM. L'amplitude s'est montrée également très réduite dans les périodes REM. L'analyse par ordinateur a donné des résultats analogues/ L'histogramme des valeurs d'amplitude de macrofluctuation pour le sommeil NREM s'est déplacé vers le zéro. Dans l'histogramme des valeurs d'amplitude de macrofluctuation pour le sommeil REM on a relevé une deuxième pointe à la limite inférieure de la répartition.

La concordance des résultats de notre analyse par ordinateur des échantillons de rythme cardiaque typiques pour l'état de comportement chez les nouveaux-nés et des échantillons correspondants du rythme cardiaque foetal n'est, d'une part, pas surprenant, car la comparaison a porté a priori sur des échantillons respectivement identiques sur le plan visuel. Aussi cette concordance prouvetelle seulement de prime abord que les échantillons de rythme cardiaque effectivement identiques ont été délimités et analy sés. D'autre part, cette conformité prouve toutefois clairement l.existence chez le nouveau-né et le foetus d.échantillons de rythme cardiaque effectivement identiques' Ceci renforce en fin de compte l'hypothèse ayant servi de base à toute l'étude et selon laquelle chez le foetus comme chez le nouveau-né il existe une alternation cyclique de la coordination nerveuse centrale qui constitue le facteur essentiel pour la variation spontanée de l'échantillon du rythme cardiaque.

Mots-clés: Activité CNS, analyse par ordinateur, cycle de sommeil, échantillon du ry thme cardiaque, enregistrement du rythme cardiaque foetal, état de comportement, foetus, ligne de base, macrofluctuation, nouveau-né.

Bibliography

[1] DALTON, K. J., G. S. DAWES, J. E. PATRICK: Diurnal, respiratory, and other rhythms of fetal heart rate in lambs. Amer. J. Obst. Gynec. 127 (1977) 414

[2] FISCHER, W. M.: Analyse und Beurteilung des Kardiotokogramms (CTG). In: FISCHER, W. M. (Ed.): Kardiotokographie, 2nd Edition, Thieme, Stuttgart 1976

[3] GROTHE, W., H. BIESEL, H. RÜTTGERS, F. KUBLI: Computerized on-line analysis and datareduction of intrapartum CTG. In: ROOTH, G., L. E. BRATTEBY, (Eds.): Digest of the 5 th European Congress of Perinatal Medicine. Abstracts of Free Communications. Almquist \& Wiksell International, Stockholm 1976

[4tde HAAN, J.: De snelle variaties in het foetale hartfrequentiepatron. Academisch Proefschrift, Van Denderen, Groningen 1971

[5] de HAAN, J., J. H. van BEMMEL, B. VERSTEEG, A. F. L. VETH, L. A. M. STOLTE, J. JANSSENS,
T. K. A. B. ESKES: Quantitative evaluation of fetal heart rate patterns. I. Processing methods. Europ. J. Obstet. Gynec. 3 (1971) 95

[6] HALLER, U.: Beziehung zwischen fetaler Herzfrequenz und fetaler Oxygenation unter der Geburt. Eine rechnergestützte Analyse. Habilitationsschrift, Heidelberg, 1973

[7] HAMMACHER, K., P. H. WERNERS: Über die Auswertung und Dokumentation von CTG-Befunden. Gynaecologia 166 (1968) 410

[8] HAMMACHER, K., K. A. HUUTER, J. BOKELMANN, P. H. WERNERS: Foetal heart frequency and perinatal condition of the foetus and newborn. Gynaecologia 166 (1968) 439

[9] HAMMACHER, K.: Fluktuation = FHF-Oszillationen, Floatingline und Baseline. In: DUDENHAUSEN, J. W., SALING, E. (Ed.): Perinatale Medizin Bd. V. Thieme, Stuttgart, 1974.

[10] HON, E. H.: An atlas of fetal heart rate patterns. Harty press Inc., New Haven Conn. 1968 
[11] International Committee on Monitoring of the Fetal Heart: Descriptive classification of intrapartum fetal heart rate. 1972

[12] JUNG, H., K.-W. PlessmanN, H. SChONLAU, G. LAMBERTI, F. K. SCHMIDT: Rechnergestützte Intensivüberwachung unter der Geburt. Z. Geburtsh. u. Perinat. 181 (1977) 158

[13] JUNGE, H. D.: Erstes Konzept für ein integriertes obstetrisches Serviceprogramm (OBSERV); a) das CTG-Monitor-Programm. In: DUDENHAUSEN, J. W., SAlING, E. (Ed.): Perinatale Medizin. Bd. IV. Thieme, Stuttgart, 1973

[14] JUNGE, H. D.: Einige Grundlagen der on line Überwachung mit CTG-Monitor-Systemen (CMS). In: FISCHER, W. M. (Ed.): Kardiotokographie, 2nd Edition. Thieme, Stuttgart, 1976

[15] JUNGE, H. D.: Behavioral states and state related heart rate and motor activity patterns in the newborn infant and the fetus ante partum. I. Technique, illustration of recordings, and general results. J. Perinat. Med. 7 (1979) 85

'[16] KARINIEMI, V., K. HUKKINEN: Quantification of fetal heärt rate variability by magnetocardiography and direct electrocardiography. Amer. J. Obst. Gynec. 128 (1977) 526

[17] KUBLI, F., H. RÜTTGERS: Kontinuierliche Registrierung der fetalen Herzfrequenz bei gleichzeitiger Wehenschreibung. Der Gynäkologe 2 (1969) 73

[18] LAROS, R. K., W. S. WONG, D. C. HEILBRON, J. T. PARER, S. M. SHNIDER, H. NAYLOR, J. BUTLER: A comparison of methods for quantitating fetal heart rate variability. Amer. J. Obstet. Gynec. 128 (1977) 381
[19] MODANLOU, H. M., R. K. FREEMAN, P. BRALY: A simple method of fetal and neonatal heart rate beat-to-beat variability quantitation: Preliminary report. Amer. J. Obst. Gynec. 127 (1977) 861 report. Amer. J. Obst. Gynec. 127 (1977) 861

[20] ORGAN, L. W., P. A. HAWRYLYSHYN, J. W. GOODWIN, J. E. MILlIGAN: Quantitative indices of short- and long-term heart rate variability. Amer. J. Obst. Gynec. 130 (1978) 20

[21] PENTTI, K.: Heart rate variation in infants with respiratory distress syndrome. Acta Paediat. Scand. (Suppl.) 250 (1974) 1

[22] PRECHTL, H. F. R.: Polygraphic studies of the fullterm newborn. 2. Computer analysis of recorded data. In: BAX, M., MAC KEITH, R. C. (Ed.): Studies in infancy, clinic in developmental medicine. Heinemann, London, 1968

[23] VÄLINÄKI, I.: Heart rate variation in full-term newborn infants. Biol. Neonate 18 (1971) 129

[24] WADE, M. E., P. J. COLEMAN, S. C. WhITE: A computerized fetal monitoring system. Obstet. and Gynec. 48 (1976) 287

[25] WATANABE, K., K. ISAWE, K. HARA: Heart rate variability during sleep and wakefulness in low birth weight infants. Biol. Neonate 22 (1973) 87

[26] YEH, S., A. FORSYTHE, E. H. HON: Quantification of fetal heart rate beat-to-beat interval differences. Obstet. and Gynec. 41 (1973) 355

Received August 2, 1978. Accepted November 24, 1978.

PD Dr. H.-D. Junge

Univ.-Frauenklinik

Josef-Schneider-Str. 4

D-8700 Würzburg 